\title{
The effectiveness of social media based on photo and video sharing towards online purchase intention
}

\author{
Daru Asih ${ }^{1}$, Teofilus $^{2}$, Timotius F.C.W. Sutrisno ${ }^{3 *}$, Cynthia Yoana ${ }^{4}$ \\ ${ }^{1}$ Faculty of Economics and Business, Universitas Mercu Buana, Jakarta, Indonesia \\ ${ }^{2,3,4}$ Faculty of Management and Business, Universitas Ciputra, Surabaya, Indonesia \\ *Corresponding author: timotius.febry@ciputra.ac.id
}

\begin{abstract}
Internet users in Indonesia have reached 88.1 million and around 79 million are active social media users. The high phenomenon of using social media which is considered quite effective for promotion and sales is used by marketers in developing their business through online marketing on social media, one of which is Instagram. Instagram becomes one of the favorite social media that can help companies simplify their business products and services. Through Instagram, entrepreneurs can interact with consumers by sharing photos and videos. For some people, online purchases made through Instagram are considered more effective and efficient in creating online purchase intentions. The purpose of this research is to find out whether Instagram's social media marketing can influence interest in buying online through mediating variables of brand awareness, value awareness, and price awareness. The research method used is quantitative research with partial least square analysis. This study used a questionnaire and was measured with a Likert scale on 240 respondents of SME's customers. The results of this study indicate that Instagram social media marketing can make online purchase intentions without additional assistance by mediating variables brand awareness, value awareness, and price awareness.
\end{abstract}

Keywords: Digital Marketing, Social Media Marketing, Brand Consciousness, Value Consciousness, Price Consciousness, Online Purchase Intention.

JEL Classification Code: M37

DOI: 10.20885/jsb.vol24.iss2.art7

\section{Introduction}

In line with the progress of the era and information technology, business people have also required an ability to keep up with these developments. The presence of supporting internet facilities makes it easier for both sellers and consumers to do selling-purchasing activities. Internet facilities can be accessed easily through various devices, such as computers, tablets, and smartphones. As of January 2016, active internet users in Indonesia have reached 88.1 million, and 79 million of them are active social media users. Referring to the data, almost one-third of the population in Indonesia currently has and uses social media. The high number of social media users is used by marketers in developing their business through online marketing on social media, such as Instagram, Facebook, or other platforms. Through the perspective of a large audience, online sales through social media should be bigger and easier to reach the target market. However, it is unfortunate because SME's sales are still not optimal and have not reached their target. It is estimated that this is caused by several factors, including the lack of consciousness from consumers on the SME's. Consciousness itself includes 3 main dimensions: brand consciousness, value consciousness, and price consciousness, this consciousness factor can directly or indirectly influence the interest of online consumer purchases. This is also supported by previous researches. The first research was a study conducted by Riorini (2018), which shows that Instagram Marketing variable has a positive effect on online buying interest through mediating variables, such as brand consciousness, value consciousness, and price consciousness, her study is supported by another research conducted by Ismail et al (2018), which also shows a significant effect of social media marketing activities on brand loyalty variables, brand consciousness, and value consciousness. However, it is different from the research results (Ceyhan, 
2019) the functional value, hedonic value and self-brand image congruency perceptions towards the Instagram page of the brand in question positively affected the purchase intention, whereas the social value and co-creation perceptions did not have a significant effect on purchase intention. Based on above background information with a different gap of research result, the researcher will conduct a study with the title of "The Effectiveness of Social Media Based on Photo and Video Sharing Towards Online Purchase Intention". The purpose of this research is to see whether social media marketing, especially Instagram marketing, can influence the customer's interest in buying online.

\section{Literature Review and Hypotheses}

Before the popularity of marketing through online media emerge, marketing activities generally would require considerable costs. Marketing through online media is increasingly popular in line with the ease of use of the internet (Aliami et al, 2017). According to Oktaviani and Rustandi (2018), digital marketing can facilitate sales promotion, such as by using social media as a marketing medium that as what has been done by many marketers today. Digital marketing can reach almost all people, anytime, in many ways. Aliami et al. (2017) said that there are two key factors to achieve success in digital marketing; the first is understanding the term AIDA (Awareness, Interest, Desire, and Action). The second is to ensure that their brands are positioning so that they can establish two-way communication with consumers. Positioning can be done through various media, but the most effective way is through social networking or social media.

Sari (2018) revealed that social media is a media specifically designed to facilitate the ease of interactive or two-way social interactions. In addition, the advantages of interactive social media are to obtain information, as well as to disseminating information (Banjaransari 2018). Therefore, social media can be seen as a medium or online facilitator that strengthens relationships between users and creates social bond. There are 3 main social media platforms according to Kotler and Keller (2016), namely online communities and forums, blogs, and social networks (such as Facebook, Youtube, Instagram, Twitter, etc).

According to Che et al, (2017), Instagram is a leading networking site that becomes a quite popular online shopping platform among young people. They say that in recent years there has been an increase in the number of Instagram users who open virtual stores or online sales. This can happen because it is quite easy to open a store online on Instagram: users only need to create Instagram accounts, upload photos of product samples and their descriptions, and encourage their followers to buy online. Kurniawan (2017) revealed that Instagram marketing is a form of marketing activity that uses all facilities provided by Instagram. This aims to increase sales and establish better communication with customers (customer relationships). The advantages of Instagram marketing include free of cost marketing and ability to create brand awareness. Whereas according to Indika and Jovita (2017), the purpose of marketing communications, including through Instagram, is to create consumer purchase intention.

According to Siddique and Rashidi (2015) brand consciousness refers to consumer orientation towards purchasing expensive and well-known brands. Ismail et al. (2018) also state that consumers with high levels of brand awareness tend to buy from more expensive and more famous brands. According to Ismail (2017) brand consciousness refers to the orientation to choose products that are already well-known and often advertised, and they will use the brand as a symbol of status and pride. Ismail (2017) also said that when consumers have brand consciousness, they will share their experiences and references through social media to other potential consumers.

Value consciousness is defined as consumers' assessment to buy products at low prices with several good qualities (Ismail, 2016). Ismail (2016) also stated that consumers with value consciousness tend to search for a balance between cheap prices and the best quality products. Odongo \& Mutari (2019) and Riorini (2018), stated that value-oriented consumers tend to look for products with a combination of price and quality that are equally superior. According to Chao and Liao (2016), the price paid by consumers when buying a product will create value. During the process, consumers will 
create value consciousness. Furthermore, the value consciousness will have an impact on consumer attitudes, which then can influence the interest of consumer purchases (Chao and Liao., 2016).

Najib et al (2016) state that price consciousness is the unwillingness of consumers to pay higher prices for a product. In other words, consumers focus on lower prices. According to Sinha (2016) and Sinha and Batra (1999) price consciousness is a characteristic that identifies consumers who are highly aware of prices and looking for prices that are being discounted; consumers focus on getting value at the lowest price. According to Rihn et al., (2018), product prices are the main determinant of consumers who focus on price consciousness for their purchase interest. Someone who spends more time focusing on prices typically has a higher price sensitivity (Chen et al., 2015).

According to Indika and Jovita (2017), consumer purchase intention emerges within the stage of consumer interest in a product, then purchase intention will emerge after consumers' awareness and perception of the product risen. The intention in online purchasing is the condition where consumers want to buy, want to repurchase products, and feel that the internet is a suitable platform to buy the product (Putri, 2015). Che et al. (2017) revealed that it is important to build consumer trust considering that online transactions are not done face-to-face; buyers usually need to trust the profile and gain useful information to better understand the product.

\section{Research Methods}

\section{Population and Sample}

The populations in this research are all SME's customers who are buying online. Purposive sampling technique is used for sampling were sampling with certain considerations based on interests or research objectives (Suharyadi and Purwanto, 2015). This research will use 240 samples, according to Hair, Hult, Ringle, and Sarstedt (2014), the number of samples can be determined from 10 times the number of indicators used in the single construct. This research uses primary data collected through respondents' answers obtained through questionnaires. In this study the measuring instrument used to measure the variables is the Likert scale. The scale used in the Likert scale is between 1 (one) to 5 (five).

Table 1. Loading factor and AVE

\begin{tabular}{llll}
\hline Variable & Indicator & Loading Factor & AVE \\
\hline Brand Consciousness & BC1 & 0.705 & 0.590 \\
& BC2 & 0.729 & \\
& BC3 & 0.660 & \\
& BC4 & 0.809 & 0.507 \\
\hline Digital Marketing & IM1 & 0.552 & \\
(Instagram) & IM3 & 0.717 & \\
& IM4 & 0.740 & \\
& IM5 & 0.787 & 0.555 \\
\hline Price Consciousness & IM6 & 0.742 & 0.517 \\
\hline
\end{tabular}

Analysis of PLS-SEM is used in this study. It allows the researchers to simultaneously test and estimate the relationship between exogenous variables and endogenous variables with many indicators. The measurement model is evaluated by testing convergent and Discriminant validity and reliability testing. Convergent validity is assessed by its loading factor (correlation between item score or component score and construct score), which based on the Rule of Thumb for loading $>$ (greater than) 0.5 is considered as practically significant. The value of discriminant validity is based 
on cross-loading measurements with constructs that are $>$ (greater than) 0.7 and greater than any other cross-loading values. Cronbach alpha reliability measurements, based on a loading indicator, must be greater than 0.7 or can be lower than 0.6. The structural model was evaluated using the Rsquare test for the dependent construct, Stone-Geisser Q-square test for predictive relevance, and Fsquare test to calculate the effect size and t-test.

The result of the R-square value can be seen on Table 2. The data shows that Instagram marketing has a tendency to influence brand consciousness by $25.2 \%$, affecting the value of consciousness by $16.7 \%$ and affecting costumers' price consciousness by $0.7 \%$. In addition, brand consciousness, value consciousness and price consciousness also mutually have a tendency to influence online purchase intention by $41 \%$.

Table 2. R-Square

\begin{tabular}{llll}
\hline Variable & $R$-Square & Composite Reliability & $R$-Square \\
\hline Brand Consciousness & 0,252 & 0,817 & 0,252 \\
Instagram Marketing & - & 0,835 & - \\
Online Purchase Intention & 0,410 & 0,902 & 0,410 \\
Price Consciousness & 0,007 & 0,714 & 0,007 \\
Value Consciousness & 0,167 & 0,810 & 0,167 \\
\hline
\end{tabular}

The Q-square value of 0.244 indicates that the model has a tendency to have been preserved and reconstructed well and has a good predictive value of relevance. Variables can be declared reliable when it has a composite value of 0.7 or higher. The composite's reliability value of each variable shows more than 0.7 . So, it can be stated that all variables are reliable. The result of the R-square value can be seen in Table 2 . The data shows that Instagram marketing has a tendency to influence brand consciousness by $25.2 \%$, affecting the value of consciousness by $16.7 \%$ and affecting costumers' price consciousness by $0.7 \%$. In addition, brand consciousness, value consciousness, and price consciousness also mutually have a tendency to influence online purchase intention by $41 \%$.

Referring to the F-square value, it can be concluded that brand consciousness variables have a small effect $(\mathrm{F}=0,034)$, which means that the brand consciousness variable has a weak predictive ability in explaining online purchase intention variables. On the other hand, value consciousness $(\mathrm{F}=0.157)$ and price consciousness $(\mathrm{F}=0.124)$ variables have medium effects on online purchase variables intention, which means that value variables and price consciousness have a moderate predictive ability in explaining the variable online purchase intention. The t-test was conducted to see the significance of the support of the initial hypothesis. Variables are stated to have a significant effect if the t-statistic is above 1.96 .

Table 3. Hypotesis Test

\begin{tabular}{lll}
\hline Relationship between the variables & T-statistics & Result \\
\hline Brand Consciousness -> Online Purchase Intention & 2,258 & Supported \\
Instagram Marketing -> Brand Consciousness & 8,586 & Supported \\
Instagram Marketing -> Online Purchase Intention & 2,583 & Supported \\
Instagram Marketing -> Price Consciousness & 1,074 & Unsupported \\
Instagram Marketing - > Value Consciousness & 6,083 & Supported \\
Price Consciousness $->$ Online Purchase Intention & 4,973 & Supported \\
Value Concsiousness -> Online Purchase Intention & 4,874 & Supported \\
\hline
\end{tabular}

The Sobel test was conducted to calculate the indirect effect of Instagram marketing variables on online purchase intention through mediating variables of brand consciousness, value consciousness, and price consciousness. Testing the effect of mediation is done by calculating the Sobel formula and t-test with the following results. 
Table 4. Sobel Test

\begin{tabular}{lllll}
\hline Relationship between the Variables & ab & Sab & t test & Note \\
\hline Instagram Marketing $\rightarrow$ Brand Consciousness $\rightarrow$ Online Purchase Intention & 0,088 & 19,411 & 0,005 & $<1,96$ \\
Instagram Marketing $\rightarrow$ Value Consciousness $\rightarrow$ Online Purchase Intention & 0,128 & 29,777 & 0,004 & $<1,96$ \\
Instagram Marketing $\rightarrow$ Price Consciousness $\rightarrow$ Online Purchase Intention & 0,028 & 5,369 & 0,005 & $<1,96$ \\
\hline
\end{tabular}

\section{Results and Discussion}

Instagram marketing has a significant influence on brand consciousness showing a coefficient of 0.502 with a t value of 8.586; where the value is greater than 1.96. This means that Instagram marketing has a positive and significant relationship to brand consciousness, hence hypothesis 1 is accepted. This is in line with the research conducted by Riorini (2018) and Ismail et al. (2018), which stated that social media marketing activities have a positive and significant influence on brand consciousness. The growth of social media users is increasingly high, especially in Indonesia, causing social media to become a good marketing medium. The purpose of overall marketing communication itself is to create brand consciousness, given that consumers who have high brand consciousness will find it easier to recognize and promote the brand. Through social media, especially Instagram, brand consciousness created in the society can continue to grow at any time.

Instagram marketing has a significant influence on value consciousness, showing a coefficient of 0.409 with a t value of 6.083 ; where the value is greater than 1.96 . This means that Instagram marketing has a positive and significant relationship to the value consciousness, hence hypothesis 2 is accepted. The result of this study is supported by researches conducted by Ismail et al., (2018) and Riorini (2018) who found that there is a significant positive effect of social media marketing activities on value consciousness. Value-oriented consumers tend to look for products with a combination of price and quality that are equally superior. This is consistent with the characteristics of Instagram users who are dominated by students. Students tend to be educated and are critical thinkers, including choosing and buying the best products, both in terms of quality and price. They tend to use Instagram to see and compare the quality of one brand to another.

Instagram marketing has a significant influence on price consciousness showing a coefficient of 0.084 with a t value of 1.074; where the value is less than 1.96. This means that Instagram marketing does not have a significant relationship to price consciousness, hence hypothesis 3 is inappropriate and rejected. The result is supported by a research conducted by Natarajan, et al., (2017) which proves that consumers who use mobile shopping applications are less sensitive to the prices of the registered products, where price sensitivity has a relationship with price consciousness because consumers will react when price changes occur (Chua, Lee, Goh and Han, 2015). However, this is not in line with a research conducted by Riorini (2018) who found a positive influence between social media marketing on price consciousness. Riorini states that consumers who are aware of product's price will use online media to compare prices, considering that online purchases promise low prices. This is comparable to Instagram social media users who are mostly millennials and based on the survey results in this study, more than half of the respondents were students. Students usually do not think long when they make decisions and are vulnerable to consumer behavior, including in making decisions to purchase products through Instagram. They tend to buy products that they see and like on Instagram without being too concerned about the prices listed.

Brand consciousness has a significant influence on online purchase intention shows a coefficient of 0.176 with a t value of 2.258, this value is greater than 1.96 . This means that brand consciousness has a positive and significant relationship to online purchase intention, hence hypothesis 4 is accepted. However, the results of this study are not in line with the research written by Chiu and Leng (2015) revealing that there is a negative influence between brand consciousness and interest in purchasing. On the other hand, the result of this study is supported by research conducted by Riorini (2018) which states that there are positive influences between brand consciousness to 
online purchase intention. This is comparable to the criteria of Instagram user respondents, most of whom are students, housewives, and professionals who prefer products with well-known brands and are often advertised, especially in Instagram social media as it is a fairly effective marketing media. Ads on Instagram can be seen through the content posted on the brand's Instagram account. Through the advertisements that they often see on Instagram, people will certainly develop an interest in buying these products.

Value consciousness has a significant influence on online purchase intention showing a coefficient of 0.409 with a $t$ value of 4.874 , where the value is greater than 1.96 . This means that the variable of value consciousness has a positive and significant relationship to online purchase intention, hence hypothesis 5 is accepted. The result of this study is supported by Rahmanita and Gunawan (2017) who stated that value consciousness has a significant positive effect on purchase interest. The results of this study are also in line with Riorini (2018) who reveals that there is a positive effect between value consciousness on online purchase intention. Consumers with value consciousness will find a balance between price and quality and will affect their buying interest. This is also consistent with the characteristics of respondents, who are Instagram users, most of whom are students and housewives who tend to think critically and thoroughly to find a balance between price and quality. So, when they have found the right balance between price and quality, their interest in purchasing online will emerge.

Price consciousness has a significant influence on online purchase intention, shown by its coefficient of 0.328 and at the value of 4.973. This value is greater than 1.96. This means that price consciousness has a positive and significant relationship to online purchase intention; hence hypothesis 6 is accepted. The results of this study are not in line with the research conducted by Santoso et al., (2016) who found that price consciousness did not influence consumer interest, but the results of this study were supported by Xie and Chaipoopirutana (2014) who through their research could prove that price consciousness has a positive significant relationship to attitude and attitude shows a strong relationship to intention in purchasing. This is by the characteristics of Instagram user respondents, most of whom are women with the profession of students and housewives who tend to compare products by focusing on finding the lowest price when buying a product. When they have found some alternatives to the lowest priced products, their purchase intention will increase.

A value of 0.05 , which is smaller than 1.96 , means that the model of indirect influence from Instagram marketing on online purchase intention is not acceptable. This means that Instagram marketing variables can affect online purchase intention directly without needing to go through other mediating variables of brand consciousness. A t value of 0.004 , which is smaller than 1.96 , means that the model of indirect influence from Instagram marketing on online purchase intention is not acceptable. This means that Instagram marketing variables can affect online purchase intention variables directly without needing to go through other mediating variables of value consciousness. A t value of 0.05 , which is smaller than 1.96, means that the model of indirect influence from Instagram marketing on online purchase intention is not acceptable. This means that Instagram marketing variables can influence online purchase intention variables directly without needing to go through other mediating variables of price consciousness.

\section{Conclusion}

Instagram marketing significantly influences brand consciousness, but brand consciousness does not have a mediating effect on Instagram marketing on online purchase intention. So it would be better if online purchase intention is directly influenced by Instagram marketing. Instagram marketing significantly influences the value of consciousness. But value consciousness does not have a mediating effect between Instagram marketing on online purchase intention. So, it would be better if online purchase intention is directly influenced by Instagram marketing variables do not significantly influence price consciousness, and price consciousness does not have a mediating effect between Insta- 
gram marketing and online purchase intention. So, it will be better if online purchase intention is directly affected by Instagram marketing. (1) Variable of brand consciousness significantly influence online purchase intention. (2) Variable value consciousness has a significant effect on online purchase intention. (3) Variable price consciousness has a significant effect on online purchase intention.

Researchers and coworkers should further optimize the use of Instagram as a medium for promoting their products and increase product sales. Future research may examine the field of marketing management, especially the development of digital marketing by social media in-depth with different research variables. A potential variable that can be examined is about the content on Instagram, or maybe put some control variables such as age or educational level, so that we can analyze further about the consumer's characteristic in social media marketing.

\section{Reference}

Aliami, S., Hakima, E.N., dan Fauji, D.A.S. (2018) Dampak Pengembangan Pemasaran Digital Pada Startups' (Studi Kasus Pada Wirausaha Baru). Vol 3 No 1.

Rihn, A., Khachatryan, H., and Wei, X. (2018). Assessing Purchase Patterns of Price Conscious Consumers. Vol 4 No 13.

Banjaransari, Y.G. (2018). Pemanfataan Instagram Sebagai Media Komunikasi Pemasaran Online Page Down Cloth Maker.

Chao, R.F, \& Liao, P.C. (2016). The Impact of Brand Image and Discounted Price on Purchase Intention in Outlet Mall: Consumer Attitude as Mediator. Vol. 12 No 2.

Che, J.W.S., Cheung, C.M.K., and Thadani, D.R. (2017). Consumer Purchase Decision in Instagram Stores: The Role of Consumer Trust.

Chen, Y., Caputo, Y., Nayga, R.M., Jr., Scarpa, R., and Fazli, S. (2015). How Visual Attention Affects Choice Outcomes: An Eye Tracking Study. in Proceedings of The 3rd International Winter Conference on Brain-Computer Interface.

Chen, Y.C., Shang, R.A., Shu, C.Y., and Lin, C.K. (2015). The Effects of Risk and Hedonic Value on the Intention to Purchase on Group Buying Website: The Role of Trust, Price and Conformity Intention. Vol. 3 No 6. 246-256

Ceyhan, A. (2019). The impact of perception related social media marketing applications on consumers' brand loyalty and purchase intention. EMAJ: Emerging Markets Journal, 9(1), 88100.

Chiu, W.S., and Leng, H.K. (2016). Consumers' Intention to Purchase Counterfeit Sporting Goods in Singapore and Taiwan. Vol. 28 No. 1, pp. 23-36.

Chua, B. L., Lee, S.H., Goh, B., and Han, H. (2015). Impacts of Cruise Service Quality and Price on Vacationers' Cruise Experience: Moderating Role of Price Sensitivity

Indika, D.R. dan Jovita, C. (2017). Media Sosial Instagram Sebagai Sarana Promosi Untuk Meningkatkan Minat Beli Konsumen. Vol 01. No. 01.

Ismail, A.R. (2017). The Influence of Perceived Social Media Marketing Activities on Brand Loyalty. Vol. 29 Issue: 1, pp.129-144.

Ismail, A.R., Nguyen, B., \& Melewar, T.C. (2018). Impact of Perceived Social Media Marketing Activities on Brand and Value Consciousness: Roles of Usage, materialism and conspicuous consumption. Vol. 12 No. 3.

Putri, J.W. (2015). Factors Affecting Customers Online Search Intention and Online Purchase Inten- 
tion using Social Networks: Case Study of Online Shop on Instagram. Vol. 3, No. 2, 232240

Kotler, P. and Keller, K.L. (2016). Marketing Management. Jakarta: PT. Indeks Kelompok Gramedia.

Kurniawan, P. (2017). Pemanfaatan Media Sosial Instagram Sebagai Komunikasi Pemasaran Modern Pada Batik Burneh. Vol 11, No 2.

Odongo, N. H., \& Motari, W. O. (2020). Consumers' perceptiveness towards store brands within supermarkets. International Journal of Construction Management, 1-10.

Oktaviani, F., dan Rustandi, R. (2018). Implementasi Digital Marketing dalam Membangun Brand Awareness. Volume 3, No. 1, 2018, hlm. 1-20.

Rahmanita, dan Gunawan, J. (2017). Analisis Pengaruh Value Consciousness dan Price Quality Association Terhadap Private Label Brand Purchase Intention Dengan Attitude Sebagai Variabel Interveining.Vol.1 No.1.

Riorini, S.V. (2018). Social Media Marketing Toward Perceptual Consciousness and its Impact on Online Purchasing Intention, Vol 21 Issue 1, 402 - 416

Sari, N. (2018). Analisis Faktor-Faktor Yang Menentukan Penggunaan Media Sosial Instagram Sebagai Media Promosi Pada Online Shop (Studi Pada Online Shop di Jalan Dr. Mansyur Medan). Ilmu Administrasi Bisnis.

Santoso, D., Najib, M., dan Munandar, J.M. (2016). Pengaruh Persepsi Risiko, Price Consciousness, Familiarity, Persepsi Kualitas, dan Citra Toko Pada Minat Beli Konsumen. Vol. 9, No.3, p: 218-230.

Siddique, S., \& Rashidi, M.Z. (2015). Influence of Social Media on Brand Consciousness: A Study of Apparel in Karachi. Vol 15 Issue 6.

Suharyadi dan Purwanto. (2009). Statistika Untuk Ekonomi dan Keuangan Modern. Jakarta: Salemba Empat.

Sinha, R. (2016). Investigating the Decision-Making Style of College Student Regarding Online Apparel Shopping.Vol 5 Issue 6

Sinha, I., Batra, R. (1999). The effect of consumer price consciousness on private label purchase. Vol 16.

Xie, X.Z., and Chaipoopirutana, S. (2014). A Study of Factors Affecting Towards Young Customers' Purchase Intention of Domestic-Branded Smartphone in Shanghai, Republic of China. 